SCientia Marina 70 (2)

June 2006, 189-202, Barcelona (Spain)

ISSN: 0214-8358

\title{
Zooplankton and ichthyoplankton distribution on the southern Brazilian shelf: an overview
}

\author{
RUBENS M. LOPES ${ }^{1}$, MARIO KATSURAGAWA ${ }^{1}$, JUNE F. DIAS ${ }^{1}$, MONICA A. \\ MONTÚ ${ }^{2(\dagger)}$, JOSÉ H. MUELBERT², CHARLES GORRI ${ }^{2}$ and FREDERICO P. BRANDINI ${ }^{3}$ \\ ${ }^{1}$ Oceanographic Institute, Dept. of Biological Oceanography, University of São Paulo, São Paulo, 05508-900, Brazil. \\ E-mail: rmlopes@usp.br \\ ${ }^{2}$ Federal University of Rio Grande, Rio Grande, 96201-900, Brazil. \\ ${ }^{3}$ Center for Marine Studies, Federal University of Paraná, Pontal do Paraná, 83255-000, Brazil. \\ (†) Deceased
}

\begin{abstract}
SUMMARY: The southern Brazilian coast is the major fishery ground for the Brazilian sardine (Sardinella brasiliensis), a species responsible for up to $40 \%$ of marine fish catches in the region. Fish spawning and recruitment are locally influenced by seasonal advection of nutrient-rich waters from both inshore and offshore sources. Plankton communities are otherwise controlled by regenerative processes related to the oligotrophic nature of the Tropical Water from the Brazil Current. As recorded in other continental margins, zooplankton species diversity increases towards outer shelf and open ocean waters. Peaks of zooplankton biomass and ichthyoplankton abundance are frequent on the inner shelf, either at upwelling sites or off large estuarine systems. However, meandering features of the Brazil Current provide an additional mechanism of upward motion of the cold and nutrient-rich South Atlantic Central Water, increasing phyto- and zooplankton biomass and production on mid- and outer shelves. Cold neritic waters originating off Argentina, and subtropical waters from the Subtropical Convergence exert a strong seasonal influence on zooplankton and ichthyoplankton distribution towards more southern areas. This brief review highlights the need for further experimental studies on zooplankton life cycle strategies in order to understand the major processes controlling food web dynamics in this shelf ecosystem.
\end{abstract}

Keywords: zooplankton, ichthyoplankton, distribution, biomass, water masses, upwelling, continental shelf, south-western Atlantic Ocean.

RESUMEN: INFLUENCIA DE LOS PROCESOS FÍSICOS EN LA DISTRIBUCIÓN DEL ZOOPLANCTON E ICTIOPLANCTON: UNA REVISIÓN DE LOS ESTUDIOS REALIZADOS EN LA COSTA SUR DE BRASIL. - La costa sur de Brasil representa la principal zona de pesca de la sardina brasileña (Sardinella brasiliensis), especie responsable de más del $40 \%$ de las capturas de especies marinas de la región. El desove y el reclutamiento están influenciados localmente por la advección estacional de aguas ricas en nutrientes procedentes tanto de fuentes costeras como oceánicas. Por otro lado, las comunidades planctónicas son controladas por procesos regenerativos asociados a la naturaleza oligotrófica del Agua Tropical procedente de la Corriente de Brasil. Como se ha observado para otros márgenes continentales, la diversidad de especies del zooplancton aumenta hacia las aguas de la plataforma externa y de océano abierto. Máximos en la biomasa de zooplancton y la abundancia de ictioplancton son frecuentes en la plataforma interna, tanto en afloramientos como en grandes sistemas estuáricos. No obstante, la formación de meandros en la Corriente de Brasil proporciona un mecanismo adicional para la ascensión de las aguas frías y ricas en nutrientes del Atlántico Sur Central, aumentando la biomasa fito- y zooplanctónica y la producción en la plataforma media y externa. Las aguas neríticas frías procedentes del estuario de La Plata y las aguas subtropicales de la Convergencia Subtropical ejercen una fuerte influencia en la distribución del zooplancton e ictioplancton hacia las regiones de más al sur. La presente revisión pone de relieve la necesidad de investigaciones más completas de las estrategias de los ciclos de vida del zooplancton con el objetivo de entender los procesos principales que controlan la dinámica de las redes tróficas en este ecosistema costero.

Palabras clave: zooplancton, ictioplancton, distribución, biomasa, masas de agua, afloramiento, plataforma continental, Atlántico Suroeste. 


\section{INTRODUCTION}

The southern Brazil shelf ecosystem accounts for over half of the country's marine fisheries yield (Matsuura, 1996; Odebrecht and Garcia, 1997). Among the locally exploited pelagic species, the Brazilian sardine (Sardinella brasiliensis) used to contribute up to $40 \%$ of total landings of marine fish, with annual catches ranging from 75,721 to 228,037 tons for the 1968 to 1986 period (Matsuura, 1996). However, fishery yields for this species have decreased dramatically in the last 20 years - not surpassing 120,000 tons per year - and catches below or around 35,000 tons per year have been the norm since 1999 (Cergole et al., 2005; FAO, 2003). This is due to over-exploitation of stocks (Cergole et al., 2005), and because of climate change and oceanographic anomalies that have led to recruitment failures (Matsuura, 1999).

Fish spawning and recruitment in this oligotrophic region depend strongly on seasonal advection of nutrient-rich waters from both inshore and offshore sources, which affects the availability of planktonic food for the larvae (Matsuura et al., 1992). Physical processes such as oceanic fronts and eddies have been intensively studied because of their implications to biological processes, including the variability of zooplankton and ichthyoplankton stocks (Iles and Sinclair, 1982; Nakata, 1989; McGowen, 1993; Sabatés and Olivar, 1996; Grioche et al., 1999). Such biological variability is, in turn, of utmost importance for the recruitment of economically important fish such as Sardinella brasiliensis.

Research into zooplankton and ichthyoplankton taxonomy and ecology has been carried out on the southern Brazilian coast since the late nineteenth century when international oceanographic expeditions such as the Challenger and Terra Nova sporadically collected samples in the region (Brandini et al., 1997). During the last 30 years a reasonable knowledge of zooplankton and ichthyoplankton mesoscale distribution in relation to major circulation systems has been gained (Katsuragawa et al., 2006; Lopes et al., 2005). However, access to the information available for the region is rather difficult for the international oceanographic community because many important papers and reports were published in local, non-indexed journals with Portuguese as the dominant language, or remain as unpublished theses and dissertations (Brandini et al., 1997). This paper intends to fill part of this gap by presenting a brief overview of the effects of major circulation processes on the distribution of zooplankton and ichthyoplankton assemblages of the area.

\section{THE REGIONAL PHYSICAL ENVIRONMENT AND FERTILIZATION MECHANISMS}

The southern Brazilian coast can be divided into two latitudinal areas according to their hydrographic features: (i) the Southern Brazilian Bight (SBB) located between Cape Frio and Cape Santa Marta (roughly $22^{\circ} 00^{\prime} \mathrm{S} 28^{\circ} 30^{\prime} \mathrm{S}$ ), and (ii) the Southern Subtropical Shelf (SSS) from Cape Santa Marta towards the border with Uruguay, but extending

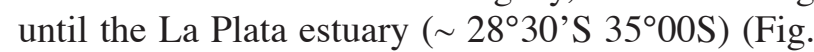
$1)$. The major contrast between these two areas comes from the stronger influence of cold coastal waters $(\mathrm{CCW})$ derived from the La Plata outflow on the SSS compared to northern latitudes (Fig. 1). In addition, the oceanic domain off the SSS is affected by seasonal changes in the latitudinal position of the northern border of the Subtropical Convergence (STC), which is derived from the confluence of the major boundary currents in the Southwest Atlantic:

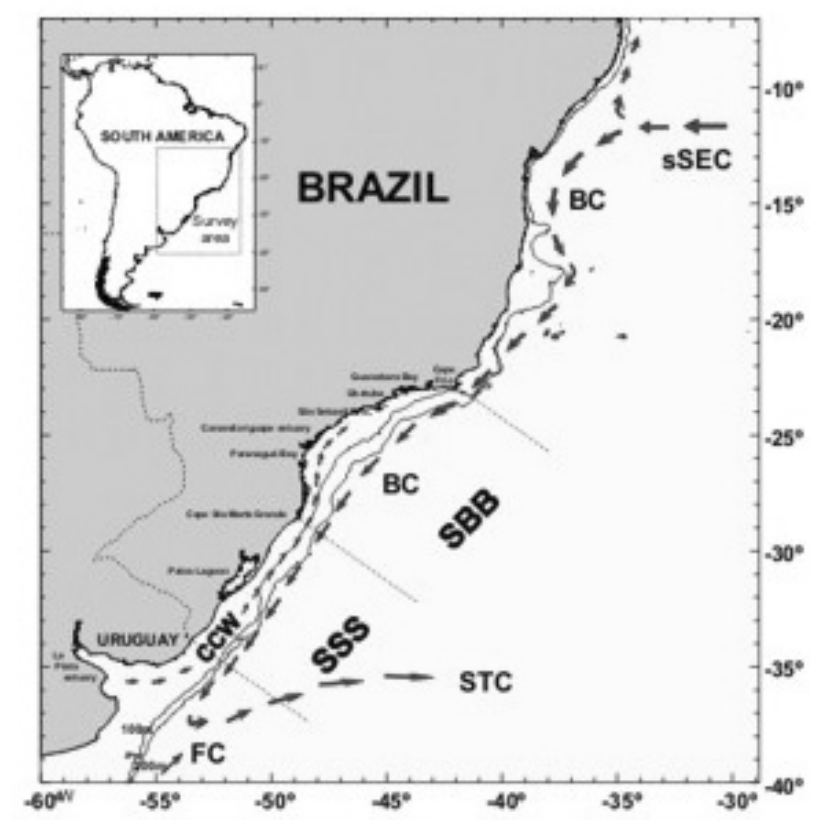

Fig. 1. - The Brazilian shelf and its two southernmost areas: the Southern Brazilian Bight (SBB) and the Southern Subtropical Shelf (SSS). Symbols: sSEC (southern branch of the South Equatorial Current), BC (Brazil Current), CCW (Cold Coastal Water), FC (Falkland Current = Malvinas Current), STC $($ Subtropical Current). Adapted from Castro Filho and Miranda (1998). 


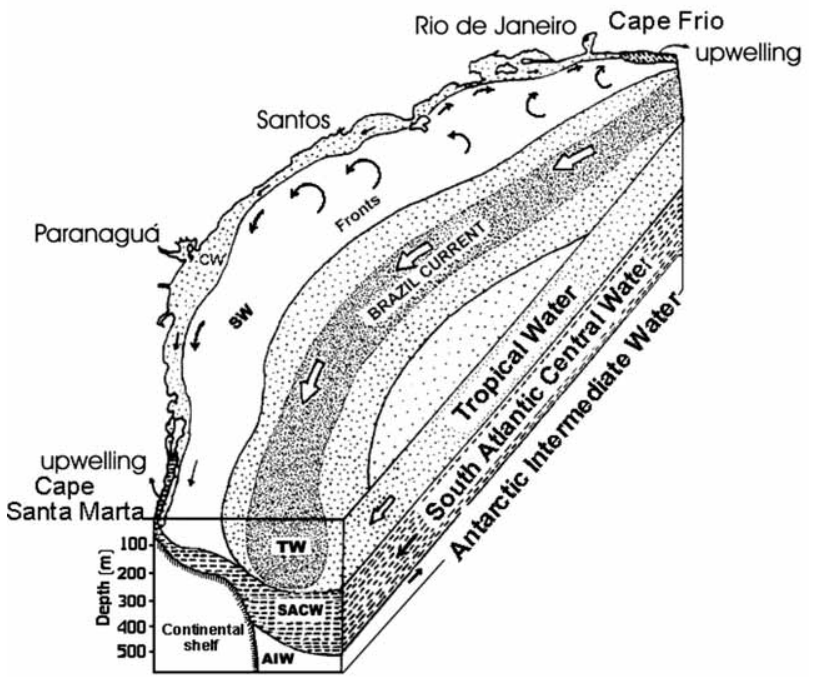

FIG. 2. - Major circulation patterns and water masses on the southern Brazilian shelf. TW: Tropical Water; SACW: South Atlantic Central Water; SW: Shelf Water; CW: Coastal Water; AIW: Antarctic Intermediate Water. From Ribeiro (1996).

the Brazil and Falklands (=Malvinas) currents (Castro Filho and Miranda, 1998).

Three different water masses characterize the neritic region of the SBB (Fig. 2). The warm Tropical Water (TW) carried by the Brazil Current flows southwards near the shelf break in the upper $200 \mathrm{~m}$ depth layer with temperature higher than $20^{\circ} \mathrm{C}$ and salinity higher than 36.40 (Castro Filho and Miranda, 1998). The cool South Atlantic Central Water (SACW), with temperature and salinity maxima below $20^{\circ} \mathrm{C}$ and 36.40 respectively is also transported southwards along the continental slope between 200 and $500 \mathrm{~m}$ by the lower layer of the Brazil Current. Coastal Water $(\mathrm{CW})$ results from mixing of shelf water (with both TW and SACW influences) with waters of continental origin, and is characterized by lower salinities (Castro Filho and Miranda, 1998; Silveira et al., 2000). Finally, Antactic Intermediate Water (AIW) flows northwards below the SACW layer in offshore areas.

The SBB and the SSS can be divided into three major bathymetric regions according to the prevailing oceanographic conditions: the inner, mid- and outer shelf. The inner shelf, where the $\mathrm{CW}$ is the main component, is distinguished from the midshelf by a bottom thermal front. The mean position of the thermal front changes seasonally: it is closer to the coast during summer (between 10 to $20 \mathrm{~km}$ from the coast), and further offshore during winter (between 40 to $50 \mathrm{~km}$ from the coast). During summer, when a seasonal and shallow thermocline occurs, a two-layered system is formed on the midshelf: below the thermocline waters derived from SACW intrusions prevail, while the upper layer is dominated by $\mathrm{CW}$ or by $\mathrm{CW} / \mathrm{TW}$ mixtures. Midshelf waters are separated from those of the outer shelf by a strong salinity front located between 80 and $120 \mathrm{~km}$ from the coast. High salinity waters from the TW are present in the surface layer, whereas in the bottom layer there is a strong influence of the SACW (Castro Filho and Miranda, 1998).

Except for the mouth of some estuarine systems, oligotrophic conditions prevail off the SBB due to TW predominance in upper layers. Oceanic stocks of nutrients are trapped below in the South Atlantic Central Water (SACW) thanks to the physical stability of permanent thermoclines. Nutrient levels within the euphotic zone are therefore low and usually controlled by regenerative processes (Metzler $e t$ al., 1997) that keep rates of organic production below $0.1 \mathrm{~g} \mathrm{C} \mathrm{m}^{-2} \mathrm{~d}^{-1}$ (Brandini et al., 1997; Gaeta and Brandini, 2006). Different physical mechanisms may be responsible for inputs of new nutrients into the euphotic zone along the SBB and on the SSS. Variations in shelf topography, wind patterns and hydrographic regime provide various opportunities of upward motions of the SACW at different time and spatial scales (Fig. 3).

Fertilization by oceanic nutrients in the SBB is the most important process in terms of geographic magnitude. Under the stress of northeast winds during summer seasons, surface shelf waters are pushed offshore following the Ekman transport, and are counteracted by onshore bottom intrusions of the SACW. This brings new nutrients shoreward, thus increasing their concentrations at lower euphotic layers. Consequently, deep chlorophyll maximum layers (DCML) are formed at subsurface levels, usually dominated by diatoms (Brandini et al., 1989; Odebrecht and Djurfeldt, 1996; Gaeta and Brandini, 2006), leading to an increase in net production between 25 and $100 \mathrm{~m}$ isobaths during spring and summer (October to March).

Cyclonic eddies ("vortex" in Fig. 3) of the Brazil Current are common mesoscale processes on the mid- and outer shelf throughout the year (Kampel et al., 2000), increasing net production up to $2.4 \mathrm{~g} \mathrm{C}$ $\mathrm{m}^{-2} \mathrm{~d}^{-1}$ in neritic domains (Gaeta et al., 1999). Shelfbreak upwelling of the SACW is enhanced by these eddies, inducing the formation of DCML along the shelf-break (Mesquita et al., 1993; Brandini et al., 1989). Gaeta and Brandini (2006) estimated the con- 


\section{(a) SUMMER}

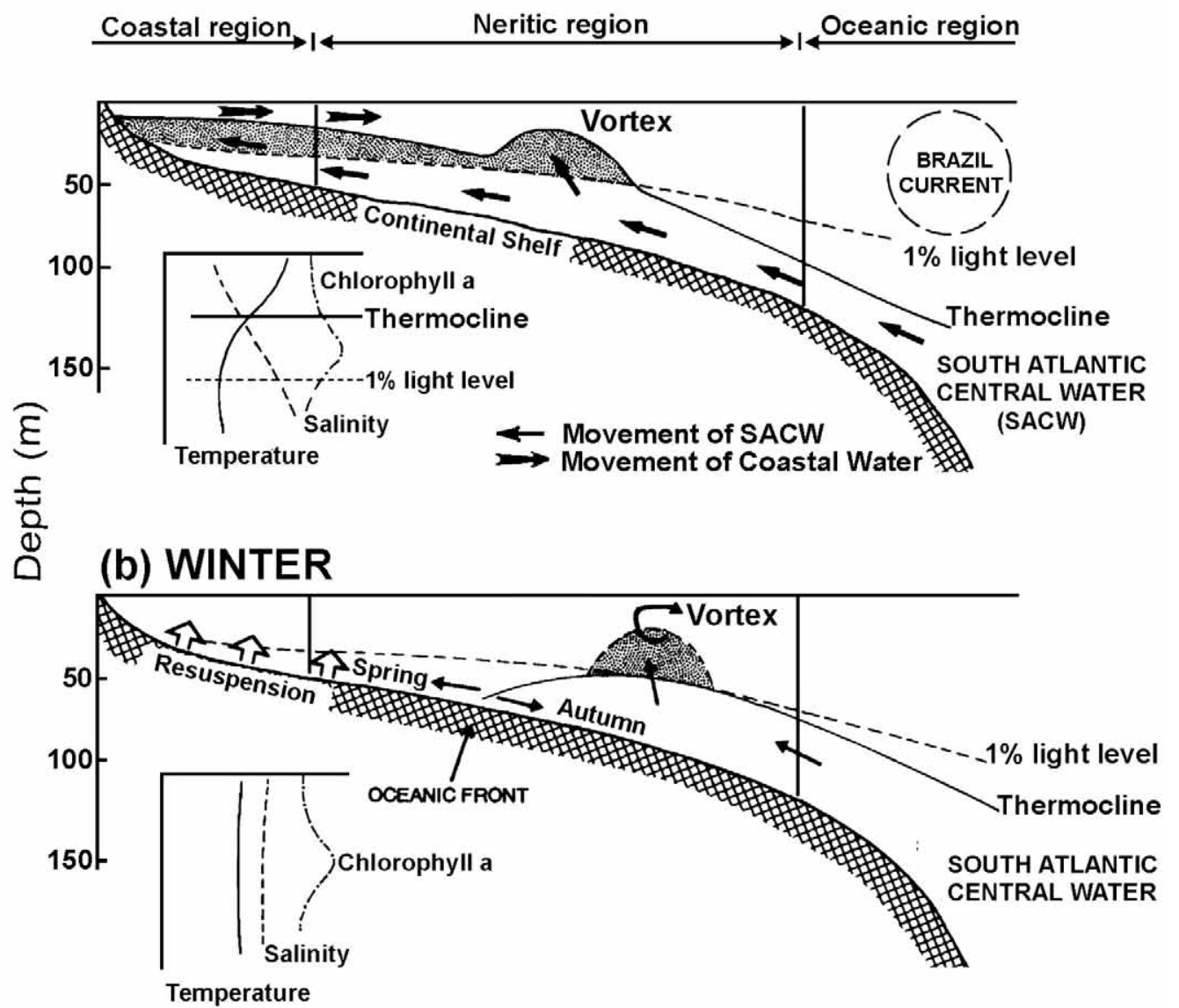

FIG. 3. - Seasonal contrasts in shelf processes off the southern Brazilian coast. Bottom intrusions of the South Atlantic Central Water (SACW) are more frequent during summer, and surface upwelling may occur at certain areas. Cold waters derived from shelf-break upwelling may also be driven towards the coast by bottom intrusions. As surface waters are dominated by Tropical Water (TW) and its mixtures with CW and SACW, a seasonal thermocline develops during summer. During winter the SACW retreats offshore and only occasionally penetrates onto the shelf. Shelf-break eddies and meanders ("Vortex" on FIGure) are more geographically confined and do not exert a strong influence on the oceanic fertilization of mid- and inner shelves. However, sediment resuspension may be a major nutrient supply to the water column in shallower areas during winter. From Matsuura (1996).

tribution of eddies along the shelf break for the annual net production of the SBB as being of the same order of magnitude as the oceanic intrusions of the SACW into the mid- and inner shelf. During summer, eddy-derived waters are pushed towards the inner shelf with SACW intrusions, but during winter eddies are short-lived and geographically restricted (Fig. 3).

Internal waves are another important mechanism of nutrient enhancement in the lower euphotic layers in the SBB (Brandini, 2006). Johannessen (1968) has reported internal waves in the SBB moving up to 20 meters on the $16^{\circ} \mathrm{C}$ isotherm towards the euphotic zone. Therefore, it is reasonable to associate chlorophyll enhancements at the levels of the DCML with upward motions of nutriclines. Sediment resuspension also plays an important role in nutrient export to the euphotic zone in shallower areas, especially during wintertime when turbulence caused by wind stress is stronger throughout the water column compared to summer (Fig. 3).

On the southernmost shelf (SSS) the same physical processes take place with the persistence of the northeast winds in summer. However, south-eastern winds prevailing in winter are responsible for mass fertilization of inner and mid-shelves with new nutrients, mainly nitrate and silicate, by pushing further north the continental discharge of the La Plata river and, to a lesser extent, the Patos Lagoon Estuary, forming the Subtropical Shelf Front (Piola et al., 2000). Primary production and chlorophyll stock in winter are indeed enhanced at these latitudes compared to summer rates at the same positions (Brandini, 1990). For this reason the algal production on the SSS is high all year round. In summer, plankton production is enhanced at the subsur- 
face by oceanic nutrients from the SACW by the physical mechanisms described above, whereas in winter the shelf system is mainly supported by land sources of nutrients from the Argentinean shelf.

\section{ZOOPLANKTON AND ICHTHYOPLANKTON COMPOSITION}

A typical inshore-offshore gradient in zooplankton diversity occurs in the regional shelf ecosystem due to differences in the pelagic food web structure between mesotrophic coastal waters and oligotrophic waters of the Brazil Current. However, physical processes described above including SACW intrusions into both the SBB and the SSS, advection of cold coastal waters during winter on the SSS, and mesoscale eddies and fronts derived from the meandering of the Brazil Current complicate this pattern. An outline of major species groups and their relation to prevailing water masses has been provided by several studies on zooplankton distribution in the study area, and a brief account is given below.

As found in other coastal ecosystems of the world, copepods are the most abundant and diversified metazoan taxa (Björnberg, 1963, 1981). Due to the tropical influence of the Brazil Current, up to 150-200 pelagic species may be found in a typical transect survey over the shelf (e.g., Vega-Perez, 1993; Montú et al., 1998; Lopes et al., 1999). Small copepods ( $<2 \mathrm{~mm}$ in total length) belonging to the genera Paracalanus, Temora, Clausocalanus, Oithona, Oncaea and Corycaeus are the most ubiquitous species in CW and in mixtures of CW and TW. Some abundant species such as Parvocalanus crassirostris, Labidocera fluviatilis, Acartia lilljeborgi and Euterpina acutifrons are restricted to estuaries and the inner shelf, disappearing under the influence of oceanic waters (Sartori and Lopes, 2000). Acartia tonsa belongs to this "true" coastal group but only towards more southern areas close to the Patos Lagoon system; north of Cape Santa Marta this species seems to be restricted to meso- and polihaline waters inside estuaries (Lopes et al., 1986, 1998).

The TW is characterized by high biological diversity, with several indicator species being easily recognized (e.g., Clausocalanus furcatus, Acartia danae, Acrocalanus longicornis, Undinula vulgaris, Euchaeta marina). Cold-water species occurring below the permanent thermocline in the oceanic domain (e.g., Haloptilus longicornis, $H$ ornatus, $H$. fertilis, Lucicutia gaussae and Centropages violaceus) often appear on the shelf during the early upwelling phase (Lopes et al., 2006). Among them, only Calanoides carinatus and Ctenocalanus vanus are able to persist in coastal areas during later upwelling and early downwelling stages when water temperature rises above $20^{\circ} \mathrm{C}$ (Valentin, 1989). Together with coastal species, such as Paracalanus quasimodo and Temora turbinata, they probably represent the major metazoan consumers of phytoplankton and microzooplankton assemblages in upwelling areas such as Cape Frio (Lopes et al., 1999). Other examples of zooplankton taxa associated with upwelling events on the southern Brazilian coast are the hydromedusae Rhacostoma atlantica and Olindias sambaquiensis (Mianzan and Guerreiro, 2001), the appendicularian Fritillaria pellucida (Campos, 2000), the chaetognaths Sagitta maxima and Krohnitta subtilis (Liang, 1998), the pteropod Hyalocylis striata (Resgalla and Montú, 1994), the euphasiids Euphausia americana, E. recurva and Stylocheiron spp. (Lansac-Tôha, 1981; Muxagata, 1999), and the "cladocerans" Penilia avirostris and Pleopis polyphemoides (Valentin, 1983). The latter are also found in coastal and estuarine waters as well as in mixtures of CW, TW, and SACW (Lopes et al., 2006). Salps are quite a diversified and abundant group in the shelf ecosystem, with 26 species recorded so far (Lopes et al., 2006). Thalia democratica is the dominant species in warm waters influenced by the Brazil Current. Although not as abundant as $T$. democratica, doliolids (Doliolium nationalis and Dolioletta gegenbauri) are also frequent close to the coast (under CW influence), and towards the outer shelf (under TW influence). Largesized thaliaceans of the genera Doliolina, Ihlea, and Salpa may occur in association with SACW intrusions (Lopes et al., 2006).

The ichthyoplankton species composition has been analyzed in detail by studies of larval fish assemblages. For example, Itagaki (1999) found three main larval groups inhabiting SBB waters down to the $100 \mathrm{~m}$ isobath, which were assigned to coastal, neritic and oceanic assemblages. A transitional group containing coastal and neritic species was also identified. For some taxonomic categories the assemblage composition reflected the adult distribution pattern and reproductive strategies. The coastal assemblage, obviously influenced by $\mathrm{CW}$, included larvae of Harengula jaguana, Synodus foetens, Chloroscombrus chrysurus, Oligoplites spp., Sphyraena guachancho, Etropus crossotus, 
Gymnachirus sp., Symphurus kyaropterygium, and other larvae of the following families: Gerreidae, Sciaenidae, Mugilidae, Blenniidae and Gobiidae. Among this group there were some species typically abundant in estuarine or low saline waters, such as $H$. jaguana and the carangids $C$. chrysurus and Oligoplites. The neritic assemblage, influenced by SACW intrusions, included fish larvae with a wide ranging distribution over the continental shelf such as Engraulis anchoita, Bregmaceros cantori, Trichiurus lepturus, Auxis sp., Bothus ocellatus, and those of the families Ophidiidae, Triglidae, and Serranidae. The oceanic assemblage was characterized by the predominance of mesopelagic taxa associated with TW including Maurolicus stehmanni, Pollichthys mauli, Diaphus dumerelli, Paralepididae and Nomeidae. A transitional larval group included species found in both coastal and neritic assemblages such as Sardinella brasiliensis, Euthynnus alletteratus, Etropus longimanus, Syacium papillosum, Symphurus trewavasae and S. jenynsi. Larvae of Engraulidae and Clupeidae, especially Engraulis anchoita, Sardinella brasiliensis and Harengula jaguana, represented up to $60 \%$ of the ichthyoplankton standing-stock in inner and intermediate shelf areas (<100 m depth; Katsuragawa et al., 2006).

\section{INFLUENCE OF PHYSICAL PROCESSES ON ZOOPLANKTON AND ICHTHYOPLANKTON MESOSCALE DISTRIBUTION}

Zooplankton biomass and ichthyoplankton abundance are usually high in coastal areas under the influence of brackish water outflow from large embayments or lagoonal systems including the Guanabara and Paranaguá bays, the CananéiaIguape estuarine system and the Patos Lagoon estuary (Vannucci and Almeida Prado, 1959; Vannucci, 1962; Moreira, 1976; Björnberg, 1981; Muxagata, 1999). Biomass maxima due to coastal zooplanktonic species are restricted to a rather narrow band influenced by $\mathrm{CW}$, decreasing towards the outer shelf regardless of the season (Navas-Pereira, 1973; Hubold and Gurgel, 1978; Hubold, 1980; Bonecker et al., 1990; Muxagata, 1999; Resgalla et al., 2001).

High zooplankton and ichthyoplankton stocks in inshore waters are otherwise associated with SACW upwelling, especially in the vicinities of Cape Frio, towards the southwest off Guanabara Bay (Rio de Janeiro) and Ubatuba, and off Cape Santa Marta
(Matsuura et al., 1980; Valentin, 1989; Muxagata, 1999). Zooplankton dry weight during the productive upwelling phase may be higher than $200 \mathrm{mg} \mathrm{m}^{-3}$, while under downwelling conditions in summer or during non-upwelling seasons biomass values below $50 \mathrm{mg} \mathrm{m}^{-3}$ are the rule (Valentin and Moreira, 1978; Monteiro-Ribas, 1988; Muxagata, 1999).

Temporal changes in spawning activity of fishes in relation to SACW intrusions are suggested by variability in total egg abundance, as observed during the course of seasonal cruises carried out in 1976 (Fig. 4). During January (mid-summer) about half of the stations had low egg densities $\left(<50\right.$ eggs $\left.\mathrm{m}^{-2}\right)$ and seven $(5.2 \%)$ high-density stations with more than 400 eggs $\mathrm{m}^{-2}$ were observed. The amount of low-density stations increased to $88.0 \%$ during May (midfall), when only one station $(0.7 \%)$ with high egg density was found. A recovery trend was observed in the subsequent cruises, as the index of high-density stations rose to $6.4 \%$ during late winter and early spring, and reached the maximum spawning activity in late spring and early summer, when $20.3 \%$ of stations had high egg density. During summer, peak egg densities were mainly located in coastal areas shallower than $100 \mathrm{~m}$ at the low-temperature $\left(<20^{\circ} \mathrm{C}\right)$ upwelling sites of Cape Frio, Rio de Janeiro and Cape Santa Marta, and also off large estuarine systems such as Paranaguá and Cananéia-Iguape where subsurface temperatures were above $22^{\circ} \mathrm{C}$.

The seasonal pattern mentioned above reflects to a great extent the situation observed for the Brazilian sardine. For instance, Matsuura (1983, 1996) found an index of positive stations for Sardinella brasiliensis eggs of $14.3 \%$ in January, then a total absence of eggs in the two subsequent cruises (May and September/October), and again $12.9 \%$ of positive stations in December. Engraulis anchoita seems to perform a different strategy, maintaining high spawning activity even during the cold season, as observed by Nakatani (1982), who found the following indexes of positive stations: $19.4 \%$ in January, $18.1 \%$ in May, $45.8 \%$ in September/October, and $20.1 \%$ in December. Peak egg densities of E. anchoita occurred in September/October (average of 32.2 eggs $\mathrm{m}^{-2}$ ). Spach (1990) and Matsuura et al., (1992) found similar results for the same species, during a survey carried out from 1985 to 1987 off São Paulo $\left(23^{\circ} \mathrm{S}\right.$ $\left.24^{\circ} \mathrm{S}\right)$. According to Spach (1990) S. brasiliensis and Harengula jaguana spawn in summer, with secondary peaks in spring and fall, and their eggs are 

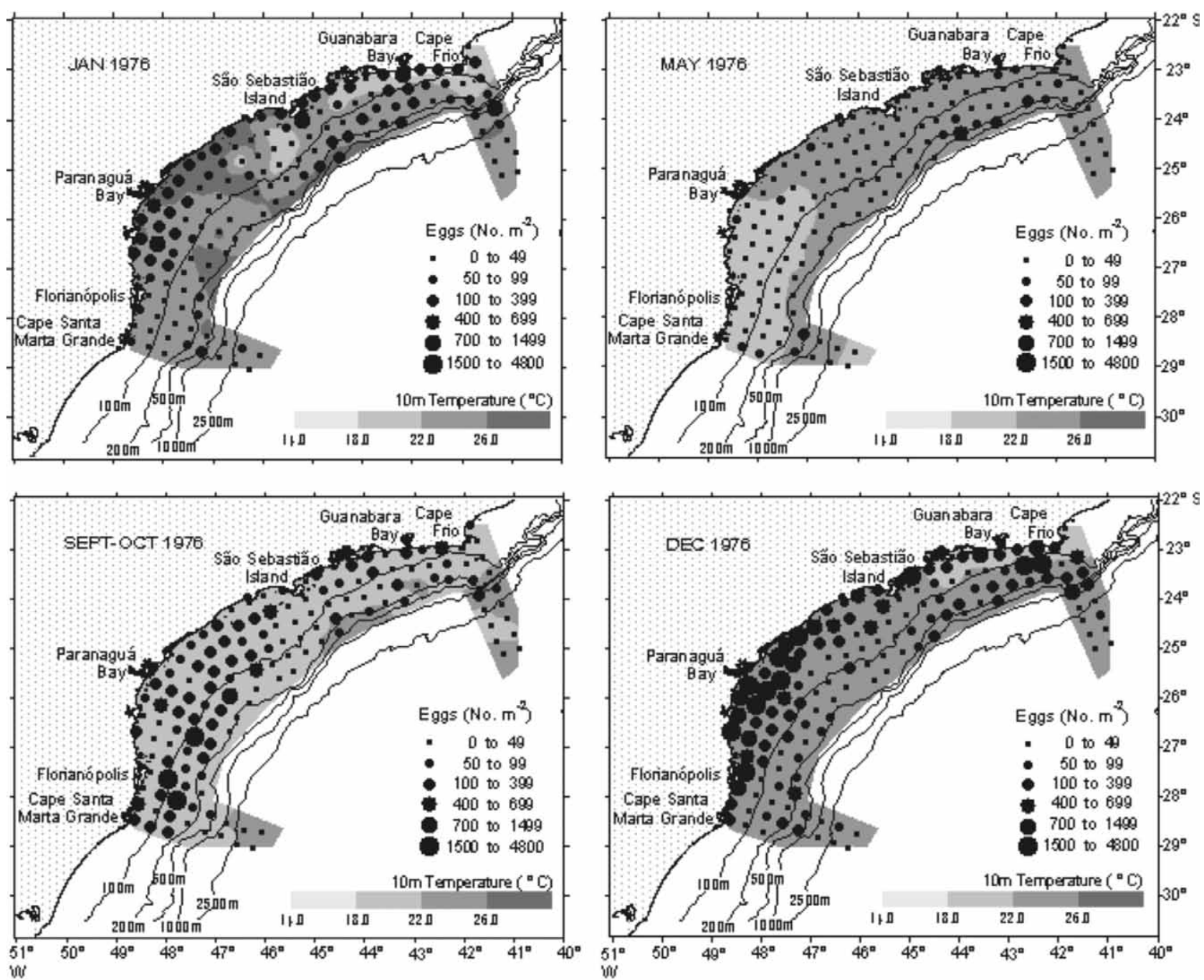

FIG. 4. - Cross-shelf and seasonal variability of fish egg abundance in the SBB during 1976. Samples were collected from $200 \mathrm{~m}$ to the surface, or close to the bottom to the surface when stations were shallower than $200 \mathrm{~m}$, by oblique tows of a Bongo net with a $500 \mu \mathrm{m}$ mesh size. A temperature contour at $10 \mathrm{~m}$ depth is shown in order to identify major upwelling areas close to the coast. Original data from Matsuura (1978).

mostly confined to shallow $(<50 \mathrm{~m})$ shelf waters during this season, predominantly distributed above the thermocline. In this case, the enrichment due to the presence of SACW and the retention of larvae within the favourable coastal habitat may be of fundamental importance for larval survival and recruitment success. Spawning of Engraulis anchoita, on the other hand, occurs all over the shelf, and does not show a clear seasonal pattern as that observed for sardines. In summary, two major spawning patterns are observed in the south-eastern Brazilian Bight: 1) higher spawning activity in summer or earlier, between late spring and summer, observed for sardines, Trachurus lathami (Katsuragawa and Matsuura, 1992) and some scombrids (Matsuura and Sato, 1981); 2) a second group exhibiting a yearround spawning pattern on the entire continental shelf, including Engraulis anchoita and Maurolicus stehmanni (Ribeiro, 1996).

A seasonal trend similar to that observed for sardines is the usual picture in the case of zooplankton (Fig. 5), but in addition to biomass agglomerations associated with low-temperature inshore areas during summer, patches also occurred on the intermediate and outer shelves (between 100 and $200 \mathrm{~m}$ depth) and close to the shelf break, following an apparently recurrent pattern observed since early quantitative studies (Jacob et al., 1966). These maxima probably result from cumulative growth of both coastal- and SACW-derived zooplankton taxa preying upon large phytoplankton aggregates that develop within upwelling systems associated with vortices and eddies of the Brazil Current (Gaeta, 1999). Since these fertilization mechanisms are at their 

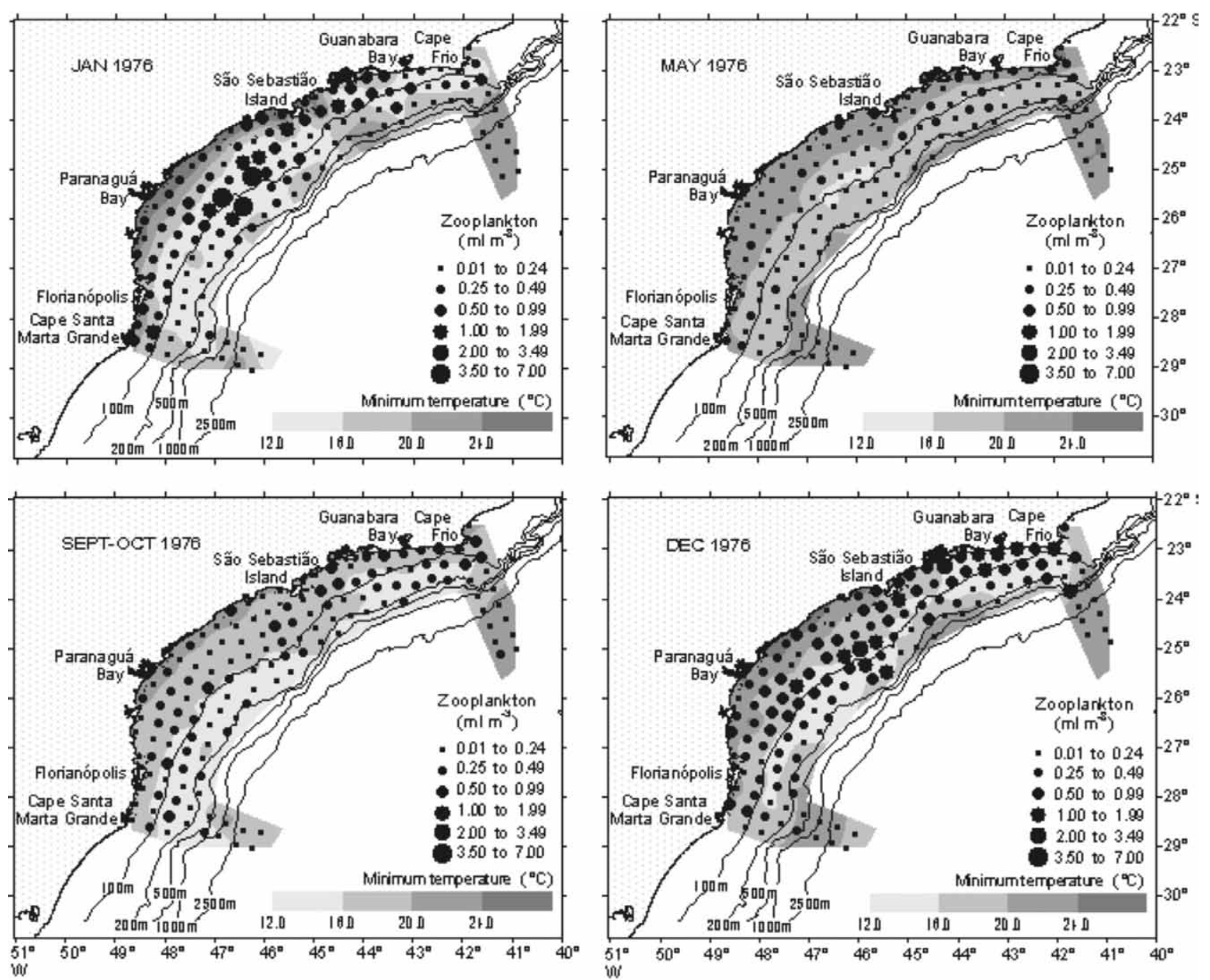

FIG. 5. - Cross-shelf and seasonal variability of zooplankton biomass in terms of displacement volume in the SBB during 1976. Samples were collected from $200 \mathrm{~m}$ to the surface, or close to the bottom to the surface when stations were shallower than $200 \mathrm{~m}$, by oblique tows of a Bongo net with a $333 \mu \mathrm{m}$ mesh size. Minimum temperatures within the depth layer of zooplankton sampling are show in order to identify major SACW intrusion areas on the shelf. Original data from Matsuura (1978).

highest during late spring and summer (although not restricted to these seasons), maximum zooplankton biomass on mid- and outer shelves is consistently observed at this time of the year (Matsuura, 1978; Matsuura et al., 1980).

Biomass accumulation of crustacean plankton and other non-gelatinous taxa in the SBB is indeed related to the persistence of cold waters in the range of 12 to $18^{\circ} \mathrm{C}$, and salp abundance follows the same pattern (Fig. 6). Salp aggregations are quite common along the entire continental shelf and their biovolume may be as high as that of other zooplankton groups combined. When they occur in such large numbers, salps supposedly have a deleterious effect on fish foraging behaviour by affecting the food environment of dietary components of fish larvae (Matsuura et al., 1980; Katsuragawa et al., 1993;
Ribeiro, 1996). However, the extent of this hypothesized impact on fish spawning and recruitment still needs to be studied in detail.

Upwelling off Cape Frio and other coastal areas of the SBB has a rather pulsing nature; each event usually lasts for 15 days or less, even during summer when north-eastern winds are at their maximum strength (Silva et al., 1988; Gonzalez-Rodriguez, 1994). Phytoplankton responses to nitrate flux occur at the same time scales, and primary production rates of $0.5 \mathrm{~g} \mathrm{C} \mathrm{m}^{-2} \mathrm{~d}^{-1}$ are common in the area (Gonzalez-Rodriguez et al., 1992). It has been argued that large zooplankters do not have a strong grazing impact on such dense but short-living phytoplankton patches because of their longer generation time compared to diatoms and other dominant microalgae (Gaeta and Brandini, 2006). Yet copepod 


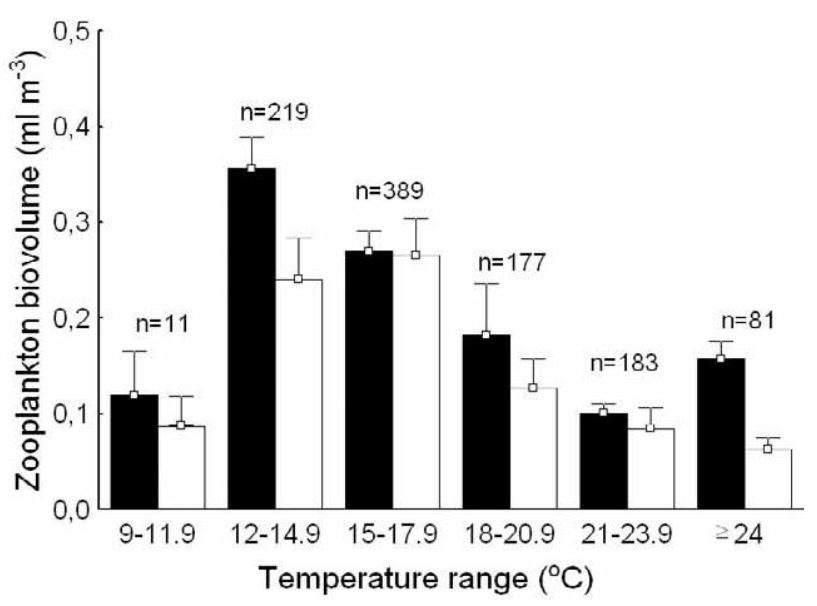

FIG. 6. - Zooplankton biovolume excluding salps (filled bars) and salp biovolume (empty bars) according to ranges of minimum temperature taken from the deepest position of Bongo net hauls (333 $\mu \mathrm{m}$ mesh size) performed on the SBB between 1975 and 1982 (1062 stations). Filled bars account for planktonic crustaceans and other non-gelatinous taxa. Original data.

biomass accumulation off Cape Frio following the onset of upwelling can be fast, in the scale of hours (Valentin et al., 1986). In addition, food web connectivity towards higher trophic levels seems to be strong in the region because the seasonal signal of the SACW intrusion regime matches the period of higher spawning activity of most nektonic populations. Short-term increases in zooplankton biomass following SACW penetration probably promotes higher survival rates during early life stages of pelagic fish such as sardines (Matsuura, 1996), carangids (Katsuragawa and Matsuura, 1992), and scombrids (Chatwin, 1997). As experimental work on zooplankton feeding and reproductive strategies is still in its infancy in the region, this hypothesis awaits validation.

SACW intrusions are also an important pathway for some fish eggs and larvae moving from oceanic to neritic regions as in the case of Maurolicus stehmanni, a typical mesopelagic species that can occasionally be found widespread over the shelf area (Weiss et al., 1988; Ribeiro, 1996). However, Ekman transport may carry eggs and larvae offshore, and depending on the extent of such advective transport, survival and growth rates of the fish larvae could be lowered (Spach, 1990). The only evidence of offshore transport impacting other zooplankton groups in the region are not related to wind-driven circulation, but rather to tidal transport of estuarine decapod larvae towards the shelf (Veloso and Valentin, 1993; Fernandes et al., 2002).

Bakun and Parrish (1990) and Bakun (1996) have discussed the remarkable similarities between the Brazilian sardine and the California sardine stocks in terms of reproductive strategies. They analyzed the main oceanic processes that may affect the reproductive habitat of coastal pelagic fish in the SBB (wind stress, Ekman transport, wind mixing index, insolation, cloud cover and sea surface temperature). The oceanographic features in this bight, mainly influenced by the large-scale boundary flow of the Brazil Current and associated upwelling regimes, contribute to creating favourable environmental conditions for the spawning activity of the Brazilian sardine in a very similar fashion to the southern California Bight and in other eastern boundary current systems. The reproductive strategy of the Brazilian sardine appears to be in close conformity with the hypotheses that correlate the environmental effects on the reproductive success of small pelagic fishes. Peak spawning occurs during summer, when the enrichment by food particles required for first-feeding larvae (Lasker, 1975) is provided by upwelling together with more frequent periods of weak winds, which help to prevent fine-scale food particle aggregations from being destroyed by wind-induced turbulent mixing. Similar to what is observed in the southern California Bight (Parrish et al., 1981), a closed gyral circulation pattern derived from the main Brazil Current flow may contribute to retaining egg and larvae in the bight, avoiding advection to offshore areas.

Reduction of SACW intrusions may lead to an increase in larval fish mortality. Oceanographic anomalies during the spawning season of 1986/87 were the main cause of the recruitment failure that occurred in the 1987 age class of the Brazilian sardine, and which led to a drastic decrease in spawning stock biomass in subsequent years (Matsuura, 1998). Low egg densities confirmed the decrease in sardine population size again in 1988 and in the spawning season of 1991/1992 (Castello et al., 1991; Matsuura et al., 1992; Cergole, 1995). Studies on nutritional condition of sardine larvae provided further evidence of unfavourable food availability during years of weak SACW intrusions on the continental shelf. This was the case for the 1990/91 and $1991 / 92$ spawning seasons, when 7 to $13 \%$ of the larvae were in a weak nutritional condition as estimated by biochemical indicators (Dias, 1995) (Table 1). During summer 1994, when the SACW penetration extended only until the mid-shelf, a more dramatic scenario was depicted off São Sebastião, 
TABLE 1. - Percentages of sardine and anchovy larvae in weak feeding and nutritional condition during the peak of the spawning season. Biochemical indicators used to analyze individual fish larvae were tryptic enzyme activity (feeding condition) and RNA/DNA ratio (nutritional condition). Relatively lower percentages of larvae in weak condition occurred during more pronounced summer intrusions of the SACW over the continental shelf (Summer 1992/1993). Data from Dias (1995) and Dias et al., (2004).

\begin{tabular}{|c|c|c|c|c|c|}
\hline & & \multicolumn{2}{|c|}{ Feeding condition } & \multicolumn{2}{|c|}{ Nutritional condition } \\
\hline & & $\mathrm{N}$ & $\%$ & $\mathrm{~N}$ & $\%$ \\
\hline \multicolumn{6}{|l|}{ CONTINENTAL SHELF } \\
\hline \multirow[t]{3}{*}{ Sardinella brasiliensis } & summer 1990/1991 & 290 & 12.7 & - & - \\
\hline & summer $1991 / 1992$ & 110 & 7.0 & - & \\
\hline & summer 1992/1993 & 120 & 5.8 & 38 & 0 \\
\hline \multirow[t]{3}{*}{ Engraulis anchoita } & summer 1990/1991 & 413 & 23.0 & - & - \\
\hline & summer $1991 / 1992$ & 433 & 9.7 & - & - \\
\hline & summer 1992/1993 & 175 & 7.4 & - & - \\
\hline \multicolumn{6}{|l|}{ INNER COAST } \\
\hline Sardinella brasiliensis & summer 1994 & 62 & 33.3 & 39 & 57.9 \\
\hline
\end{tabular}

where 33 and $58 \%$ of the larvae were in bad feeding and nutritional conditions respectively (Dias et al., 2004). Moreover, during this season high percentages of dead larvae (24 to 63\%) were found.

The nutritional condition of the southern anchovy larvae (Engraulis anchoita) off Brazil is related to SACW intrusions in a similar fashion. However, this species occurs throughout the entire year and its distribution seems to be related to other oceanographic features. Freire and Castello (2000) suggested that winter is the favourable foraging season for E. anchoita in southern offshore waters. During this season, probability of prey consumption increases because of fertilization effects associated with shelf-break upwelling, strong vertical stability in the water column, and high production in the coastal region. Clemmesen et al. (1997) found anchovy larvae in better conditions in the stratified water column, whereas Sieg (1998) suggested that in the case of this species starvation was more significant for larval fish mortality than predation. High percentages (up to 23\%) of anchovy larvae in a bad feeding condition occurred in the SSB during austral summers of 1990-1991 and 1991-1992, decreasing to $7.4 \%$ in the $1992-1993$ summer (Table 1) when the SACW retreated to the outer shelf.

Geographical features such as islands may also influence the oceanic current systems and contribute to retention or dispersive mechanisms for fish egg and larvae. Results of a small-scale study around the São Sebastião island in the southeast coast (Katsuragawa et al., 2006) showed a tendency of fish larvae to concentrate at a particular portion of the study area, coinciding with an increase in nutrient and plankton concentration. Brazilian sardine larvae could have more survival capability due to better feeding and nutritional condition at this specific area (Dias et al., 2004). The oceanographic structure, including the local current system flowing from southwest to northeast (thus in the opposite direction from the main flow of the Brazil Current), as well as the presence of the island, act together to favour larval and food retention. In addition, SACW intrusions and continental run-off may provide further nutrient inputs to the area (Gianesella-Galvão et al., 1997). This situation may contribute to raising optimal conditions for larval development, leading to a high reproductive success of local fish populations.

As mentioned earlier, the SSS is influenced strongly by the dynamics of the Subtropical Confluence, by the freshwater contribution from Patos Lagoon and La Plata River, and by wind action over the ocean surface (Castello and Möller, 1977; Lima et al., 1996; Garcia, 1997). The importance of these processes to the distribution and abundance of zooplankton and early life stages of fish have been demonstrated by many studies, e.g., Matsuura and Kitahara (1995), Muelbert and Sinque (1996), and Sieg (1998).

Contrasting with the observed high primary production and chlorophyll concentration on the SSS during summer, zooplankton biomass due to copepods and other crustacean plankton is usually low along the entire shelf at this time of the year, except in areas under the direct influence of the continental drainage of Patos Lagoon. Such distribution pattern might be related to negative impacts associated with salp outbreaks in summer (Meneghetti, 1973; Navas-Pereira, 1973; Hubold 1980). On the other hand, high zooplankton biovolumes contributed by copepods and - to a lesser extent-by euphausids occur during winter and spring on offshore areas 
affected by the Subtropical Convergence, and also towards inshore areas under the influence of cold coastal waters advected from the Argentinean shelf (Montú et al., 1998).

Nearshore waters of the SSS are strongly influenced by continental runoff and have low salinity values. This region is dominated by estuarine and coastal species of zooplankton and fish larvae (Montú et al., 1998; Sinque and Muelbert, 1998). Dominant fish larvae in low-temperature waters of the intermediate shelf belong to the anchovy Engraulis anchoita. Larval fish diversity increases towards the shelf break $(\sim 200 \mathrm{~km}$ from the coast) where high-salinity Tropical Waters (TW) from the Brazil Current (BC) dominate. The importance of water column stability, larval transport and retention, as well as enrichment processes for selecting the reproductive habitat of Engraulis anchoita was discussed by Lima and Castello (1995).

Several fish species in southern Brazil are dependent on the Patos Lagoon as a nursery ground, especially Micropogonias furnieri, Lycengraulis grossidens, Brevoortia pectinata and Mugil spp. (Muelbert and Weiss, 1991; Sinque and Muelbert, 1998). The transport of fish eggs and larvae is related to variations in local circulation patterns of coastal currents (Muelbert and Weiss, 1991; Vieira and Scalabrin, 1991). Most of this variability is determined by the dynamics of freshwater outflow from the lagoon and wind-induced penetration of seawater into the estuary (Costa et al., 1988). Busoli (2001) has demonstrated that when freshwater outflow increases, recirculation cells provide a mechanism for concentration and retention of anchovy eggs and larvae. During periods of low freshwater influence, shelf circulation is predominantly northwards and the area becomes unfavourable for larval retention. Recent evidences suggest that anomalous periods of freshwater outflow, linked to ENSO events, have a profound effect on the diversity of young fish in the Patos Lagoon estuary (Garcia et al., 2001).

\section{CONCLUDING REMARKS}

Zooplankton investigations conducted in the study area have provided a notion on how water mass distribution affects species composition and density patterns along relatively coarse temporal and mesoscale gradients (coast-ocean, north-south, summer-winter, etc.). Detailed information on physical-biological coupling is still lacking because zooplankton sampling strategies failed to cover spatial and temporal scales relevant to key physical processes such as SACW intrusions, shelf-break upwelling associated with eddies and meanders of the Brazil Current, and CCW advection towards northern areas. In addition to implementing more refined sampling methods, there is an urgent need for experimental work on dominant zooplanktonic species in order to estimate basic process rates such as ingestion, egestion, growth, and mortality in the study area (Lopes et al., 2005). These measurements are critical in order to understand food web dynamics, including the relationships between fish spawning and planktonic food availability.

The influence of oceanographic processes on larval fish development, distribution, abundance, dietary composition, and preferred spawning periods has been reasonably well investigated in the case of pelagic species such as sardines, anchovies, scombrids and carangids. However, similar studies with other species must be encouraged. Studies on the interaction between physical processes and ichthyoplankton are important in order to obtain more information on ecological and oceanographic aspects of the early life history of fish and a more adequate understanding of the variability of recruitment of fishery resources (Castello and Haimovici, 1991; Heath, 1992).

Eddies and frontal processes are regarded as important mechanisms for retention and concentration of zooplankton and fish larvae towards the shelf (Lima and Castello, 1995). However, there is still very little knowledge about transport processes along the shelf break in this region. Understanding the mechanisms and degree of interchange between neritic and oceanic domains should help to clarify the dynamics of plankton communities and recruitment to fishery stocks of pelagic species.

\section{ACKNOWLEDGEMENTS}

We thank M. L. Zani Teixeira and K. Suzuki for their continuous technical assistance during the course of our studies, and particularly in the preparation of this manuscript. Dr. M. Pilar Olivar (Institut de Ciències del Mar - CSIC) and two anonymous reviewers gave many useful suggestions that helped to improve the initial version of the text. 
Authors RML and JHM acknowledge the Brazilian funding agency $\mathrm{CNPq}$ for financial support (grants 308055/2004-7 and 305969/2003-0 respectively).

\section{REFERENCES}

Bakun, A. - 1996. Patterns in the ocean: ocean processes and marine population dynamics. California Sea Grant/CIB, La Paz.

Bakun, A. and R.H. Parrish. - 1990. Comparative studies of coastal pelagic fish reproductive habitats: The Brazilian sardine (Sardinella aurita). J. Cons. Int. Explor. Mer., 46: 269-283.

Björnberg, T.K.S. - 1963. On the marine free-living copepods off Brazil. Bolm Inst. oceanogr., S Paulo, 13: 3-142.

Björnberg, T.K.S. - 1981. Copepoda. In: D. Boltovskoy (ed.), Atlas del Zooplancton del Atlantico Sudoccidental y metodos de trabajo con el zooplancton marino, pp. 587-679. INIDEP, Mar del Plata.

Bonecker, A.C.T., C.R. Nogueira, S.L.C. Bonecker, L.H.S. Santos, C.O. Dias, J.M.L. Reis and A. S. Dias. - 1990. Distribution and diversity of zooplankton off Rio de Janeiro (RJ - Brazil). In: II Simpósio de Ecossistemas da Costa Sul e Sudeste Brasileira: Estrutura, Função e Manejo, pp. 171-178. ACIESP, São Paulo.

Brandini F.P. - 2006. Hidrografia e produção biológica na região sudeste-sul do Brasil, no contexto do Programa REVIZEE. In: C.L.D.B. Rossi-Wongtschowski and L.S. Madureira (coord.), $O$ Ambiente oceanográfico da Plataforma Continental e do Talude na Região Sudeste-Sul do Brasil, pp. 447-460. Editora da USP, São Paulo.

Brandini, F.P. - 1990. Hydrography and characteristics of the phytoplankton in shelf and oceanic waters off southeastern Brazil during winter (July/August 1982) and summer (February/March 1984). Hydrobiologia, 196: 111-148.

Brandini, F.P., R.M. Lopes, K.S. Gutseit, H.L. Spach, and R. Sassi. - 1997. A Planctonologia na Plataforma Continental do Brasil: Diagnose e Revisão Bibliográfica. Ministério do Meio Ambiente e da Amazônia Legal, IBAMA, Brasília.

Brandini, F.P., C.L.B. Moraes, and C.A.Thamm. - 1989. Shelf break upwelling, subsurface maxima of chlorophyll and nitrite, and vertical distribution of a subtropical nano- and microplankton community off southeastern Brazil. In: F.P. Brandini (ed.), Memórias do III Encontro Brasileiro de Plâncton. p. 47-56. Editora UFPR, Curitiba.

Busoli, R.O. - 2001. Transporte e retenção de ovos e larvas de Engraulis anchoita na Plataforma Continental Sul do Brasil. M.Sc. dissertation, Fundação Universidade Federal do Rio Grande.

Campos, M. A. G. - 2000. As Appendicularia (Chordata: Tunicata) da região compreendida entre Cabo Frio (RJ) e Cabo de Santa Marta Grande (SC). M.Sc. dissertation, Universidade de São Paulo.

Castello, J.P. and M. Haimovici. - 1991. Simpósio da FURG sobre pesquisa pesqueira: comentários e recomendações. Atlântica, Rio Grande, 13: 5-9.

Castello, J.P. and O.O. Möller. - 1977. On the oceanographic conditions in the Rio Grande do Sul State. Atlântica, Rio Grande, 2: $25-110$

Castello, J.P., R.P. Habiaga, J.C. Amaral and I.D. Lima Jr. - 1991. Prospecção hidroacústica e avaliação da biomassa de sardinha e anchoíta, na região sudeste do Brasil (outubro/novembro de 1988). Publção esp. Inst. oceanogr., S Paulo, 8: 15-29.

Castro Filho, B.M. and L.B. Miranda. - 1998. Physical oceanography of the western Atlantic continental shelf located between $4^{\circ} \mathrm{N}$ and $34^{\circ} \mathrm{S}$ coastal segment $\left(4^{\circ} \mathrm{W}\right)$. In: A.R. Robinson and K.H. Brink (eds.), The sea, pp. 209-251. John Wiley and Sons, New York.

Cergole, M.C. - 1995. Stock assessment of the Brazilian sardine, Sardinella brasiliensis, of the southeastern coast of Brazil. Sci. Mar., 59: 597-610.

Cergole, M.C. and C.L.D.B. Rossi-Wongtschowski. - 2005. Sardinella brasiliensis (Steindachner, 1879). In: M.C. Cergole, A.O. Ávila-da-Silva and C.L.D.B Rossi-Wongtschowski. (eds.), Análise das principais pescarias comerciais da região sudeste-sul do Brasil: Dinâmica populacional das espécies em explotação, Série Documentos REVIZEE - Score Sul, pp. 145 150. Instituto Oceanográfico - USP, São Paulo.

Chatwin, A.C. - 1997. Estimativa da abundância do bonito pintado, Euthynnus alletteratus, e do bonito cachorro, Auxis spp. (Teleostei: Scombridae) na costa sudeste brasileira. Ph.D. thesis, Universidade de São Paulo, São Paulo.

Clemmesen, C., R. Sanchez and C.L.D.B. Rossi-Wongtschowski. 1997. A regional comparison of the nutritional condition of SW Atlantic anchovy larvae, Engraulis anchoita, based on RNA/DNA ratios. Arch. Fish. Mar. Res., 45: 17-43.

Costa, C., U. Seeliger and P. Kinas. - 1988. The effect of wind velocity and direction on the salinity regime in the lower Patos Lagoon estuary. Ciência e Cultura, 40(9): 909-912.

Dias, J.F. - 1995. Avaliação da condicão nutricional das larvas de sardinha-verdadeira (Sardinella brasiliensis Steindachner 1879) Clupeidae e da anchoíta (Engraulis anchoita Hubbs and Marini, 1935) Engraulididae, da costa sudeste do Brasil. Ph. D. thesis. Universidade de São Paulo, São Paulo.

Dias, J.F., C. Clemmesen, B. Ueberschär, C.L.D.B. Rossiwongtschowski and M. Katsuragawa - 2004. Condition of the Brazilian sardine, Sardinella brasiliensis (Steindachner, 1879) larvae in the São Sebastião inner and middle continental shelf (São Paulo, Brazil). Brazil. J. Oceanogr., 52: 81-87.

FAO - 2003. FAO yearbook. Fishery statistics: capture production Vol. 92/1. FAO, Rome.

Fernandes, L.D.A., S.L.C. Bonecker and J.L. Valentin. - 2002 Dynamic of decapod crustacean larvae on the entrance of Guanabara Bay. Brazilian Arch. Biol. Technol., 45: 491-498.

Freire, K.M.F. and J.P. Castello. - 2000. Feeding habits of Engraulis anchoita larvae off southern Brazil. Bolm Inst. Pesca, S. Paulo, 26: 189-201.

Gaeta, S.A. - 1999. Produção Primária na Região Oeste do Atlântico Sul. Full Professorship thesis, Universidade de São Paulo.

Gaeta, S.A. and F.P. Brandini. - 2006. Produção primária do fitoplâncton na região entre o Cabo de São Tomé (RJ) e o Chuí (RS). In: C.L.D.B. Rossi-Wongtschowski and L.S. Madureira (coord.), O Ambiente oceanográfico da Plataforma Continental e do Talude na Região Sudeste-Sul do Brasil, pp. 219-264. Editora da USP, São Paulo.

Gaeta, S.A., J.A Lorenzzetti, L.B. Miranda, S.M.M. Susini-Ribeiro, M. Pompeu and C.E.S. Araujo. - 1999. The Vitoria Eddy and its relation to the phytoplankton biomass and primary productivity during the austral fall of 1995. Arch. Fish. Mar. Res., 47: 253-270.

Garcia, A., J.P. Vieira and K. Winemuller. - 2001. Dynamics of the shallow-water fish assemblage of the Patos Lagoon estuary (Brazil) during cold and warm ENSO episodes. J. Fish Biol., 59: $1218-1238$.

Garcia, C.A.E. - 1997. Physical Oceanography. In: U. Seeliger, C. Odebrecht and J.P. Castello (eds), Subtropical Convergence Environments: The Coast and Sea in the Southwestern Atlantic. Springer-Verlag, Heidelberg.

Gianesella-Galvão, S. M. F., E. Aidar, L..A. Vega-Pérez and F.M.P. Saldanha-Corrêa. - 1997. Distribuição do plâncton na região costeira de São Sebastião. Publção esp. Inst. oceanogr., S Paulo, 41: 5-14.

Gonzalez Rodriguez, E., J.L.. Valentin, D.L. André and S.A. Jacob. - 1992. Upwelling and downwelling at Cabo Frio (Brazil): Comparison of biomass and primary production responses. $J$. Plankton Res., 14: 289-306.

Gonzalez Rodriguez, E. - 1994. Yearly variation in primary productivity of marine phytoplankton from Cabo Frio (RJ, Brazil) region. Hydrobiologia, 294: 145-156.

Grioche, A., P. Koubbi and X. Harlay. - 1999. Spatial patterns of ichthyoplankton assemblages along the eastern English Channel, French coast, during spring 1995. Est. Coast. Shelf Sci., 49: 141-152.

Heath, M.R. - 1992. Field investigations of the early life stages of marine fish. Adv. Mar. Biol., 28: 1-174.

Hubold, G. - 1980. Hydrography and plankton off Southern Brazil and Rio de La Plata, August-November 1977. Atlântica, 4: 1-22.

Hubold, G. and I. Gurgel. - 1978. Plankton volumes, temperature and salinity distribution off Rio de Janeiro. "Preliminary results of the cruise "Operação Rio de Janeiro" 06-17/06/77. Publ. Inst. Pesq. Marinha, 131: 1-9.

Iles, T. D. and M. Sinclair. - 1982 Atlantic herring: stock discrete- 
ness and abundance. Science, 215: 627-633.

Itagaki, M.K. - 1999. Composição, abundância e distribuição horizontal de larvas de peixes marinhos e sua relação com os fatores hidrográficos na costa sudeste do Brasil. M.Sc dissertation, Universidade de São Paulo.

Jacob, S.A., L.M. Braga and R. Barth. - 1966. Observações planctonológicas na costa do Brasil. Notas Técnicas Inst. Pesq. Mar., 24: 1-18.

Johannessen, O.M. - 1968. Note on some hydrographical and current observations from three positions on the Brazilian shelf in the region of Cabo frio-Santos, 1966. Contrções Inst. Oceanogr. Univ. S Paulo, sér. Ocean. Fís., 10: 1-8.

Kampel, M., J.A. Lorenzzetti, S.A. Gaeta, C.S.E. Araujo and A.T. Assireu. - 2000. Use of satellite data for studying and monitoring the southeast cost of Brazil. In: Proceedings do IX Simposio latinoamericano en percepcion remota y sistemas de informacion espacial, pp. 1033-1044. Puerto Iguazu, Argentina.

Katsuragawa, M. and Y. Matsuura. - 1992. Distribution and abundance of carangid larvae in the Southeastern Brazilian Bight, during 1975-1981. Bolm Inst. oceanogr., S Paulo, 40: 55-78.

Katsuragawa, M., J.H. Muelbert and J.F. Dias. - 2006. O ictioplâncton na região entre o Cabo de Sâo Tomé (RJ) e o Chuí (RS). In: C.L.D.B. Rossi-Wongtschowski and L.S. Madureira (coord.), O Ambiente oceanográfico da Plataforma Continental e do Talude na Região Sudeste-Sul do Brasil, pp. 359-446. Editora da USP, São Paulo.

Katsuragawa, M., Y. Matsuura, K. Suzuki, J.F. and H.L. Spach. 1993. O ictioplâncton ao largo de Ubatuba, SP: composição, distribuição e ocorrência sazonal (1985-1988). Publ. esp. Inst. oceanogr., S. Paulo, 10: 85-121.

Lansac-Tôha, F.A. - 1981. Chaves de identificação e diagnose das espécies de Euphausiacea (Crustacea) encontradas ao largo da costa sul do Brasil (Lat. $\left.22^{\circ} \mathrm{S}-29^{\circ} \mathrm{S}\right)$. Rev. brasil. Biol., 51: 623-638.

Lasker, R. - 1975. Field criteria for survival of anchovy larvae: the relation between inshore chlorophyll maximum layers and successful first feeding. Fish. Bull., U.S., 73: 453-462.

Liang, T.H. - 1998. Estudo dos Chaetognatha epiplanctônicos da região de São Sebastião $\left(23^{\circ} 30^{\prime} \mathrm{S}-24^{\circ} 25^{\prime} \mathrm{S}, 4^{\circ} 55^{\prime} \mathrm{W}-44^{\circ} 55^{\prime} \mathrm{W}\right)$ e da região compreendida entre os Penedos de São Pedro e São Paulo $\left(01^{\circ} \mathrm{N}, 29^{\circ} \mathrm{W}\right)$ e o Cabo Frio. Ph. D. thesis. Universidade de São Paulo.

Lima, I.D. and J.P. Castello. - 1995 Distribuition and abundance of South-west Atlantic anchovy spawners (Engraulis anchoita) in relation to oceanographic processes in the southern Brazilian shelf. Fish. Oceanogr., 4: 1-16.

Lima, I.D., C.A.E Garcia and O.O. Möller Jr. - 1996. Ocean surface processes in the Southern Brazilian shelf: characterization and seasonal variability. Cont. Shelf Res., 16: 1307-1317.

Lopes, R.M., M.S. Almeida Prado-Por and F.D. Por. - 1986. Zooplankton seasonality in the Rio Verde Estuary. Rev. Hydrobiol. trop., 19: 207-214.

Lopes, R.M., R. Vale and F.P. Brandini. - 1998. Composição, abundância e distribuição espacial do zooplâncton no complexo estuarino de Paranaguá durante o inverno de 1993 e o verão de 1994. Rev. bras. oceanogr., 46: 195-211.

Lopes, R.M., F.P. Brandini and S.A. Gaeta. - 1999. Distribution patterns of epipelagic copepods off Rio de Janeiro (SE Brazil) in summer 1991/1992 and winter 1992. Hydrobiologia, 411: 161-174.

Lopes, R.M., M.A. Montú and C. Gorri. - 2005. Estudos sobre zooplâncton marinho no Brasil: Avaliação crítica e perspectivas. In: E.C.G. Couto and G.R.A. Rocha (eds.), Biodiversidade marinha no Brasil. EDITUS, Ilhéus. (in press)

Lopes, R.M., M.A. Montú, C. Gorri, E. Muxagata, L. Miyashita and L.P. Oliveira - 2006. O zooplâncton marinho da região entre o Cabo de São Tomé (RJ) e o Chuí (RS). In: C.L.D.B. RossiWongtschowski and L.S. Madureira (coord.), O Ambiente oceanográfico da Plataforma Continental e do Talude na Região Sudeste-Sul do Brasil, pp. 265-358. Editora da USP, São Paulo.

Matsuura, Y. - 1978. Exploração e avaliação de estoque de peixes pelágicos no sul do Brasil (novembro de 1975 a novembro de 1977) - Projeto integrado para uso e exploração racional do ambiente marinho. Rel. Técn., Inst. oceanogr., Universidade de São Paulo, 46 p.

Matsuura, Y. - 1983. Estudo comparativo das fases iniciais do ciclo de vida da sardinha-verdadeira, Sardinella brasiliensis $e$ da sardinha-cascuda, Harengula jaguana, (Pisces: Clupeidae) e nota sobre a dinâmica da população da sardinha-verdadeira na região sudeste do Brasil. Full Professorship thesis. Universidade de São Paulo.

Matsuura, Y. - 1996. A probable cause of recruitment failure of the Brazilian sardine, Sardinella aurita population during the 1974/75 spawning seasons. S. Afr. J. mar. Sci., 17: 29-35.

Matsuura, Y. - 1998. Brazilian sardine (Sardinella brasiliensis) spawning in the southeast Brazilian Bight over the period 19761993. Rev. brasil. oceanogr., 46: 33-43.

Matsuura, Y. - 1999. Large-scale fluctuations of small pelagic fish populations and climate change: a review. Bull. Tohoku Natl. Fish. Res. Inst., 62: 195-205.

Matsuura, Y. and E.M. Kitahara. - 1995. Horizontal and vertical distribution of anchovy Engraulis anchoita eggs and larvae off Cape Santa Marta Grande in southern Brazil. Arch. Fish. Mar. Res., 42: 239-250.

Matsuura, Y. and G. Sato - 1981. Distribution and abundance of scombrid larvae in southern Brazilian waters. Bull. Mar. Sci., 31: 824-832.

Matsuura, Y., K. Nakatani and S.T.J. Tamassia. - 1980. Distribuição sazonal de zooplâncton, ovos e larvas de peixe na região centro-sul do Brasil (1975-77). Bolm Inst. oceanogr., S. Paulo, 29: 231-235.

Matsuura, Y., H.L. Spach and M. Katsuragawa, M. - 1992. Comparison of spawning patterns of the Brazilian sardine (Sardinella brasiliensis) and anchoita (Engraulis anchoita) in Ubatuba region, southern Brazil during 1985 through 1988. Bolm Inst. oceanogr., S Paulo, 40: 101-115.

McGowen, G.E. - 1993. Coastal ichthyoplankton assemblages, with emphasis on the Southern California Bight. Bull. Mar.Sci., 53: 692-722.

Meneghetti, J.O. - 1973. Zooplankton from Southern Brazil. 1. Quantitative aspects. Iheringia (Zool.), 43: 60-74.

Mesquita, A.R., J.B.A. Leite and R. Rizzo. - 1993. Note on the shelfbreak upwelling off the southeast coast off Brazil (Lat. 26 30'S). Bolm. Inst. oceanogr., S Paulo, 32: 193-198.

Metzler, P.M., P.M. Glibert, S.A. Gaeta and J. Lublan. - 1997. New and regenerated production in the South Atlantic off Brazil. Deep-Sea Res., 44: 363-384.

Mianzan, H.W. and R.A. Guerreiro. - 2001. Environmental patterns and biomass distribution of gelatinous macrozooplankton. Three study cases in the south-western Atlantic Ocean. Sci. Mar., 64 (suppl. 1): 215-224.

Monteiro Ribas, W. M. - 1988. Os copépodos na região de Cabo Frio: variação qualitativa e quantitativa durante um ciclo de ressurgência, Rio de Janeiro, R. J., Brasil. M.Sc. dissertation, Universidade Federal do Rio de Janeiro.

Montú, M., I. Gloeden, A.K. Duarte and C. Resgalla. - 1998. Zooplâncton. In: U. Seeliger, C. Odebrecht and J.P. Castello (eds), Os ecossistemas costeiro e marinho do extremo sul do Brasil, pp. 43-46. Editora Ecoscientia, Rio Grande.

Moreira, G.S. - 1976. Sobre a migração vertical diária do plâncton ao largo de Santos, Estado de São Paulo, Brasil. Bolm Inst. oceanogr., S. Paulo, 25: 55-76.

Muelbert, J.H. and C. Sinque. - 1996 Distribution of bluefish (Pomatomus saltatrix) larvae along the continental shelf off Southern Brazil. Mar. Freshwater Res., 47: 311-314.

Muelbert, J.H. and G. Weiss. - 1991 Abundance and distribution of fish larvae in the channel area of the Patos Lagoon Estuary, Brazil. In: Larval Fish Recruitment and Research in the Americas. NOAA Tech. Rep. NMFS 95: 43 - 54.

Muxagata, E. - 1999. Avaliação da biomassa e distribuição zooplanctônica na plataforma continental Sudeste Brasileira durante o inverno de 1995. M.Sc. dissertation. Fundação Universidade Federal do Rio Grande.

Nakata, H. - 1989. Transport and distribution of fish eggs and larvae in the vicinity of coastal fronts. Rapp. pro-verb. Réu. Cons. internation. Explor. Mer, 191: 153-159.

Nakatani, K. 1982. Estudos sobre ovos e larvas de Engraulis anchoita (Hubbs and Marini, 1935) (Teleostei, Engraulidae), coletados na região entre Cabo Frio $\left(23^{\circ} S\right)$ e Cabo de Santa Marta Grande $\left(29^{\circ} S\right)$. M.Sc. dissertation. Instituto Oceanográfico, Universidade de São Paulo.

Navas-Pereira, D. - 1973. Análise qualitativa e quantitativa do zooplâncton. Publ. Esp. Inst. oceanogr., S. Paulo, 3: 29-92. 
Odebrecht, C. and L. Djurfeldt. - 1996. The role of nearshore mixing on the phytoplankton size structure off Santa Marta Cape, southern Brazil (Spring 1989). Arch. Fish. Mar. Res., 43: 217230.

Odebrecht, C. and V.M.T. Garcia. - 1997. Phytoplankton. In: U. Seeliger, C. Odebrecht and J.P. Castello (eds), Subtropical convergence environments, pp. 105-109. Springer Verlag, Heidelberg.

Parrish, R.H., C.S. Nelson and A. Bakun. - 1981. Transport mechanisms and reproductive success of fishes in the California Current. Biol. Oceanogr., 1: 175-203.

Piola, A.R., E.J.D. Campos, O.O. Möller Jr, M. Charo and C. Martinez. - 2000. The subtropical shelf front off eastern South America. J Geophys Res., 105: 6565-6578.

Resgalla Jr., C. and M.A. Montú. - 1994. Distribuição espacial e temporal de Pteropoda Euthecosomata (Mollusca, Gasteropoda) na plataforma do Sul do Brasil. Atlântica, 16: 99-123.

Resgalla Jr., C., C. D.L. Rocha and M.A. Montú, M. A. - 2001. The influence of Ekman transport on zooplankton biomass variability off southern Brazil. J. Plankt. Res., 23: 641-650.

Ribeiro, M.R. - 1996. Estudo sobre o desenvolvimento larval, abundância e distribuição de ovos e larvas de Maurolicus muelleri (Gmelin, 1789) (Teleostei: Sternoptychidae), e possíveis potencialidades ao largo da costa sudeste brasileira entre $23^{\circ} S$ (Cabo Frio-RJ) e 29 $S$ (Cabo de Santa Marta Grande-SC). M.Sc. dissertation, Universidade de São Paulo.

Sabatés, A. and M.-P. Olivar. - 1996. Variation of larval fish distribution associated with variability in the location of a shelfslope front. Mar. Ecol. Prog. Ser., 135: 11-20.

Sartori, L.P. and R.M. Lopes. - 2000. Seasonal variability of pelagic copepod assemblages on the inner shelf off Paraná, Brazil. Nauplius: $79-88$.

Sieg, A. - 1998. A study on the histological classification of the in situ nutritional condition of larval South-west Atlantic anchovy, Engraulis anchoita Hubbs and Marini, 1935. Arch. Fish. Mar. Res., 46: 19-36.

Silva, N.M.L., J.L. Valentin and C.T.B.T. Bastos. - 1988. O microfitoplâncton das águas costeiras do litoral fluminense (Estado do Rio de Janeiro): lista de espécies e aspectos ecológicos. Bolm Inst. oceanogr., S. Paulo, 36: 1-16.

Silveira, I.C.A., A.C.K. Schmidt, E.J.D. Campos, S.S. Godoi and Y. Ikeda. - 2000. A Corrente do Brasil ao largo da costa leste brasileira. Rev. bras. oceanogr., 48: 171-183.

Sinque, C. and J.H. Muelbert. - 1998. Ictioplâncton. In: U. Seeliger, C. Odebrecht and J.P. Castello (eds.), Os ecossistemas costeiro e marinho do extremo sul do Brasil, pp. 56-60. Editora Ecoscientia, Rio Grande.

Spach, H.L. - 1990. Estudo comparativo da distribuição espaçotemporal e de padrões de agregação de ovos e larvas de Harengula jaguana, Sardinella brasiliensis (Clupeidae: Osteichthyes) e Engraulis anchoíta (Engraulidae: Osteichthyes) na costa sudeste do Brasil. Ph.D. thesis, Universidade de São Paulo.

Valentin, J.L. - 1983. L'écologie du plancton dans la remontée de Cabo Frio (Brésil). Ph.D. thesis, Univ. Aix-Marselle II.

Valentin, J.L. - 1989. A dinâmica do plâncton na ressurgência de Cabo Frio - RJ. In: F.P. Brandini (ed.), Memórias do III Encontro Brasileiro de Plâncton, pp. 25-35. Universidade Federal do Paraná, Curitiba.

Valentin, J.L and A.P. Moreira. - 1978. A matéria orgânica de origem zooplanctônica nas águas da ressurgência de Cabo Frio (Brasil). An. Acad. Bras. Ciên., 50: 103-112.

Valentin, J.L., N.M. Lins da Silva, W.M. Monteiro-Ribas, M.A. Mureb, C.T.B.T. Bastos, D.R. Tenenbaum, D.L. André, S.A. Jacob and E. Pessotti. - 1986. Le plancton dans l'upwelling de Cabo Frio (Brésil): Microrépartition spatio-temporelle à une station fixe. Ann. Inst. oceanogr., 62: 117-135.

Vannucci, M. - 1962. Preliminary results on the study of the zooplankton standing stock of south Brazilian coast, $25 \infty$ lat. S. Contrib. av. Inst. oceanogr., S Paulo, 3: 1-28.

Vannucci, M. and M.S. Almeida Prado. - 1959. Sobre as coletas de plâncton na III e IV viagens do N/OC "Almirante Saldanha". Contr. av. Inst. oceanogr., S Paulo, 1: 1-16.

Vega-Perez, L. A. - 1993. Estudo do zooplâncton da região de Ubatuba, Estado de São Paulo. Publ. esp. Inst. oceanogr., S. Paulo, 10: 65-84.

Veloso, V.G. and J.L. Valentin. - 1993. Larval distribution and seasonal abundance of Emerita brasiliensis Schimitt,1935 (Decapoda, Hippidae) in southern Brazil. Rev. brasil. Biol., 53: 131-141.

Vieira, J.P. and Scalabrin, C. - 1991 Migração reprodutiva da "Tainha" (Mugil platanus Günther, 1980) no Sul do Brasil. Atlântica, Rio Grande, 13: 131-141

Weiss, G., G. Hubold and A.C.T. Bonecker. - 1988. Eggs and larvae of Maurolicus muelleri (Cymelin, 1789) (Teleostei, Sternoptychidae) in the southwest Atlantic. Meeresforsch., 32: 53-60.

Scient. ed: M.P. Olivar

Received October 6, 2004. Accepted September 14, 2005. 